\title{
Tektonikai jelenségek a Mecsekalja-öv pannóniai rétegeiben: Pécs, Ifjúság útja és környéke
}

\section{Sebe Krisztina ${ }^{1}$ - Konrád Gyula ${ }^{2}$ - Horváth Judit ${ }^{3}$}

'egyetemi adjunktus, Pécsi Tudományegyetem, Földtani és Meteorológiai Tanszék, E-mail: sebe@gamma.ttk.pte.hu ${ }^{2}$ ny. egyetemi docens, Pécsi Tudományegyetem, Földtani és Meteorológiai Tanszék, E-mail: konradgyula@t-email.hu ${ }^{3}$ doktorandusz, Pécsi Tudományegyetem, Földtudományok Doktori Iskola, E-mail: judit.of.horvath@gmail.com

Absztrakt
A Mecsek déli határán húzódó Mecsekalja-öv a Dél-Dunántúl egyik legfontosabb töréses öve, jelentöségét a késö-miocénben és azután is zajló mozgások is meghatározzák. A Kárpát-medence nagy részéhez hasonlóan a pannóniai és kvarter üledékek közti jelentös hiátus, valamint a laza üledékekben a vetökarcok hiánya miatt a különbözö mozgási fázisok idöpontjának és kinematikájának meghatározása itt is nehézségekbe ütközik. Ezek behatárolásához segitséget adhat a pannon-tavi litorális képzödmények eredetileg közvetlen közelröl származó törmelékanyagának vizsgálata. A Mecsekalja-öv legjobban feltárt szakaszán, a pécsi Ifjúság útja környékén a pannóniai durvatörmelékes képzödményeket vizsgáltuk tektonikai és szedimentológiai szempontból. A közelmúltban létesült ideiglenes feltárások dokumentálása mellett fó célunk a tektonikai elemek mérése, a kavicsanyag közettani leirása makroszkópos megfigyelések és vékonycsiszolatok segitségével, valamint a forrásközetek azonositása volt. Az eredményeket fúrási adatokkal összevetve rekonstruáltuk az ösföldrajzi képet, a tópart közetanyagának tér-és időbeli változását, ezzel az egyes közettestek mozgását. A Congeria rhomboidea molluszka-biozónába tartozó ősmaradványok alapján a vizsgált üledékek a késö-miocén viszonylag fiatal szakaszáról, a 8-6 millió év közötti időszak egy részéröl tanúskodnak. Az oligomikt, alig koptatott törmelék és az üledékszerkezetek tanúsága szerint a Pannon-tó hullámverése itt meredek, sziklás partot ostromolt, ahova betorkolló folyók nem szállitottak számottevö hordalékot. A homokba települö, koptatatlan törmeléket tartalmazó kavicsrétegeket legvalószinübben szinszediment vetömozgás üledékeiként értelmezhetjük és a feltolódások aktivitásához köthetjük. A kavicsrétegek változatos törmelékanyaga arra utal, hogy az üledékképzödés ideje alatt már egymás mellett helyezkedett el a Mecsekalja-övben ma látható, igen eltérö közettípusok nagy része. A vetözóna egyes elemei a homokos rétegsor lerakódása elött, alatt és után is mozogtak: az alaphegységi közetblokkok helyzete kis mértékben változott egymáshoz és a pannon-tavi üledékekhez képest is. Az elmozdulások túlnyomórészt eltolódásos és feltolódásos jellegüek voltak. A miocén óta a hegység emelkedése az elötérhez képest a Mecsekalja-öv mentén néhány 10 - néhány 100 m közé tehető.

Kulcsszavak Mecsek, késö-miocén, szinszediment, tektonika

\section{Bevezetés}

A Mecsek déli határán húzódó Mecsekalja-öv a Dél-Dunántúl egyik legfontosabb töréses öve. Vadász (1935) klasszikus műve óta közismert, hogy a vetőzóna mentén mozgások zajlottak a pannóniai (felső-miocén) üledékek lerakódása alatt és után is (részletesen ld. Konrád \& Sebe 2010 és hivatkozásai).

E rendkívül összetett vetózóna legjobban feltárt része Pécs város belterületén helyezkedik el. Ezen belül a Makár-hegy déli és keleti előterében, az Ifjúság útján és környékén található feltárások a Mecsekalja-öv menti fiatal, késő-neogén-kvarter deformáció léptékébe engednek bepillantást: a Pannon-tó késő-miocén üledékei változatos alaphegységi képződmények, így paleozoos metamorfitok, alsó-jura kőszenes összlet és középső-triász sziliciklasztos és karbonátos üledékek alatt, fölött és között fordulnak elő (Hámor, 1966, Kleb, 1973, Chikánné Jedlovszky \& Kókai, 1980).

A vetőzóna pannóniai és poszt-pannóniai mozgásainak 
elkülönítése legtöbbször nehéz, mivel a pannon-tavi üledékek fölött jelentős hiánnyal, eróziós diszkordanciával települnek a jóval fiatalabb, rendszerint késő-pleisztocén terresztrikus képződmények. Emellett akár a szinszediment, akár a későbbi mozgások irányának megállapítása is ritkán lehetséges, hiszen a túlnyomórészt homokból álló összlet csak kivételes esetben őriz meg pontos kinematikai indikátorokat, például vetőkarcokat. A vető menti elmozdulások korának és irányának behatárolásához segítséget adhat a pannon-tavi litorális képződmények törmelékanyagának vizsgálata (Konrád, 1998). A partközelben, hullámveréses övben lerakódott homokokban található kavicsanyagot részben a tó abráziós tevékenysége, részben a szárazföldröl történő (folyóvízi vagy areális) behordás szolgáltathatta. A kavicsok vizsgálata emiatt információval szolgál a közvetlen közelben elhelyezkedő partszakasz kőzettani felépítéséröl. Amennyiben a kavicsanyag nem egyezik a homok közelében ma megtalálható alaphegységi kőzettestekével, az azt jelenti, hogy az eredeti forráskőzet a kavicsrétegek lerakódása óta eltelt időben szerkezeti mozgások hatására eltávolodott. A mozgások jellegéhez további adatokat nyerhetünk a pannóniai üledékekben esetlegesen megfigyelhető vetők elemzésével.

Míg az Ifjúság út közeli régi homokbányák ma már csak korlátozottan vizsgálhatók, a közelmúlt építkezései során létesültek új feltárások is, például a Pécsi Tudományegyetem Szentágothai Kutatóközpontjának alapozása során. Jelen munka célja a Makár-hegy környékén a pannóniai rétegsorok kavicsanyagának és a lehetséges forráskőzetül szolgáló kibúvásoknak a kőzettani vizsgálatával, valamint szerkezetföldtani mérések és elemzések segítségével a szerkezetföldtani kép pontosítása.

\section{Kutatási terület}

\section{Földtani felépítés}

A Makár-hegy délkeleti előterét, elsősorban az Ifjúság útjától északra húzódó, mintegy $500 \mathrm{~m}$ széles sávot vizsgáltuk, amely a Mecsekalja-öv északi peremén helyezkedik el (1. ábra). Ez a kis terület rendkívül változatos felépítésü, tektonikusan érintkeznek a paleozoos, mezozoos és felső-miocén kőzetek.

A feltárt felső-miocén kavicsos homok rétegsorok anyaga a Mecsek kiemelt tömbjéröl származik, rétegtanilag a Kállai Kavics Formációba sorolható.
Ennek kora jelenlegi ismereteink szerint molluszka-biosztratigráfia alapján a Mecsekben megközelítőleg 10-től $\sim 6$ millió évig terjed (Sebe et al., 2015).

\subsection{Vizsgált feltárások}

A pannóniai kavicsbetelepüléses homok rétegsorok öt feltárását vizsgáltuk. Elhelyezkedésüket a 2. ábra mutatja, rövid leírásukat az alábbiakban adjuk. Mivel ezeket a szakirodalomban különböző néven említik, hasznosnak tartjuk megadni ezeket az elnevezéseket az eligazodás megkönnyítése végett.

\section{Ifjúság úti homokbánya}

A pannóniai képződményeket ért szerkezeti mozgások klasszikus megjelenési helye, Hámor $(1966,1970)$ és Kleb (1973) Makár-hegyi homokbányaként mutatja be. A Pécsi Tudományegyetem orvosi karának „B” kollégiuma (Balassa János Kollégium, Jakabhegyi út 6.) mögött, attól északra húzódó feltárás, erősen beakácosodva és részben leomolva. A mintegy $15 \mathrm{~m}$ magas falat pannóniai kavicsbetelepüléses homok alkotja. A homokra alsó-jura szenes összlet és paleozoos gránit (Hámor, 1970), Chikánné Jedlovszky \& Kókai (1980; MA.76 sz. feltárás) szerint metamorfit (Somogyi általuk idézett leírásában gneisz; Somogyi, 1976a, 4661. sz. feltárás) tolódott. Ezek az alaphegységi képződmények a korábbi publikációkban említett helyükön már nem láthatóak, de a PTE Szentágothai Kutatóközpont építése során a bánya keleti végében feltáródtak.

Wein (1966) Ifjúság úti homokbányaként és Ifjúsági

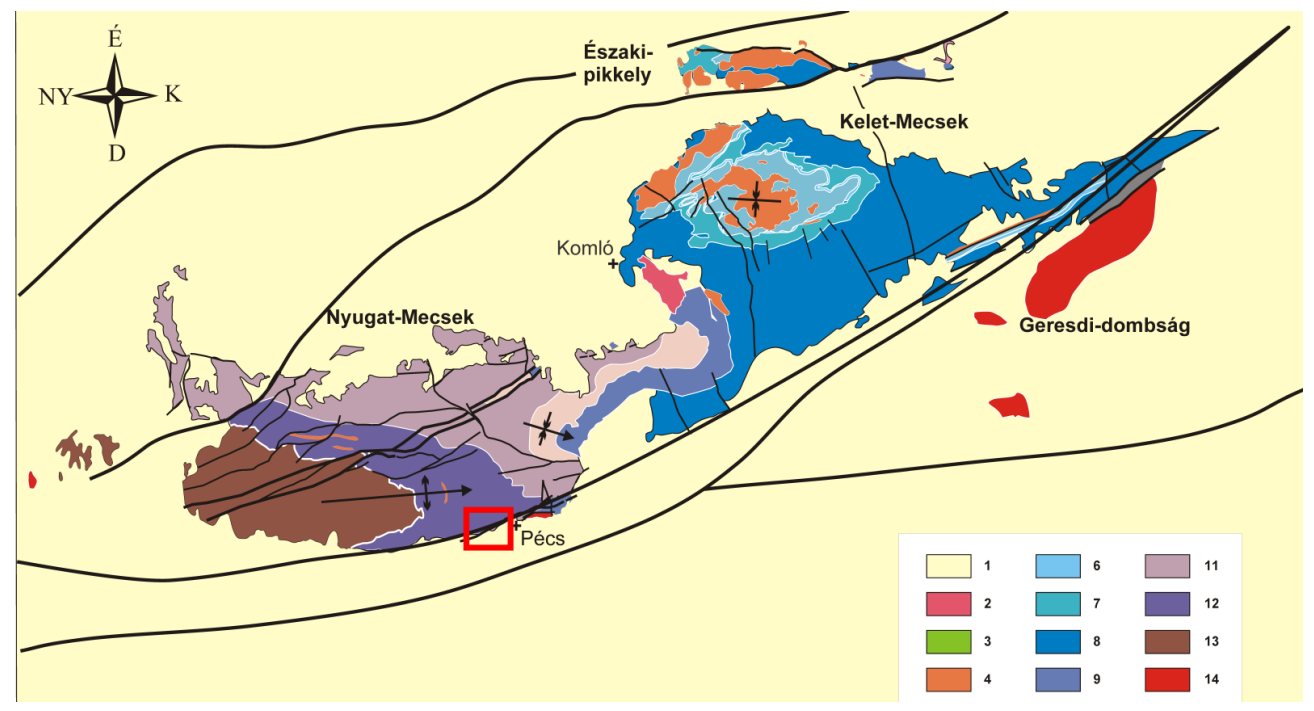

1. ábra: A kutatási terület elhelyezkedése

1. Neogén-negyedidőszaki fiatal fedőüledékek, 2. Miocén andezit, 3. Kréta üledékes kôzetek, 4. Kréta bazalt (Mecsekjánosi Bazalt Formáció), 5. Felső-jura üledékes kőzetek, 6. Középsô- felsô-jura üledékes kôzetek, 7. Középső-jura ammoniteszes mészkő, 8. Alsó- középső-jura üledékes kőzetek, 9. Középső-triász - alsó-jura kőszéntelepes összlet (Mecseki Kôszén Formáció), 10. Felsô-triász homokkô (Karolinavölgyi Homokkő Formáció), 11. Középső-triász karbonátos sorozat (Misinai Formációcsoport), 12. Alsó- középső-triász törmelékes és karbonátos üledéksor (Jakabhegyi Homokkő, Patacsi Aleurolit, Hetvehelyi Formáció), 13. Alsó-perm törmelékes és vulkáni eredetú kőzetek, valamint középső-, felső-perm - alsó-triász törmelékes üledékes kőzetek, 14. Paleozoos gránit-monzonit (Mórágyi Komplexum), 15. Paleozoos metamorf kőzetek. Piros kerettel jelölve a vizsgált terület. 


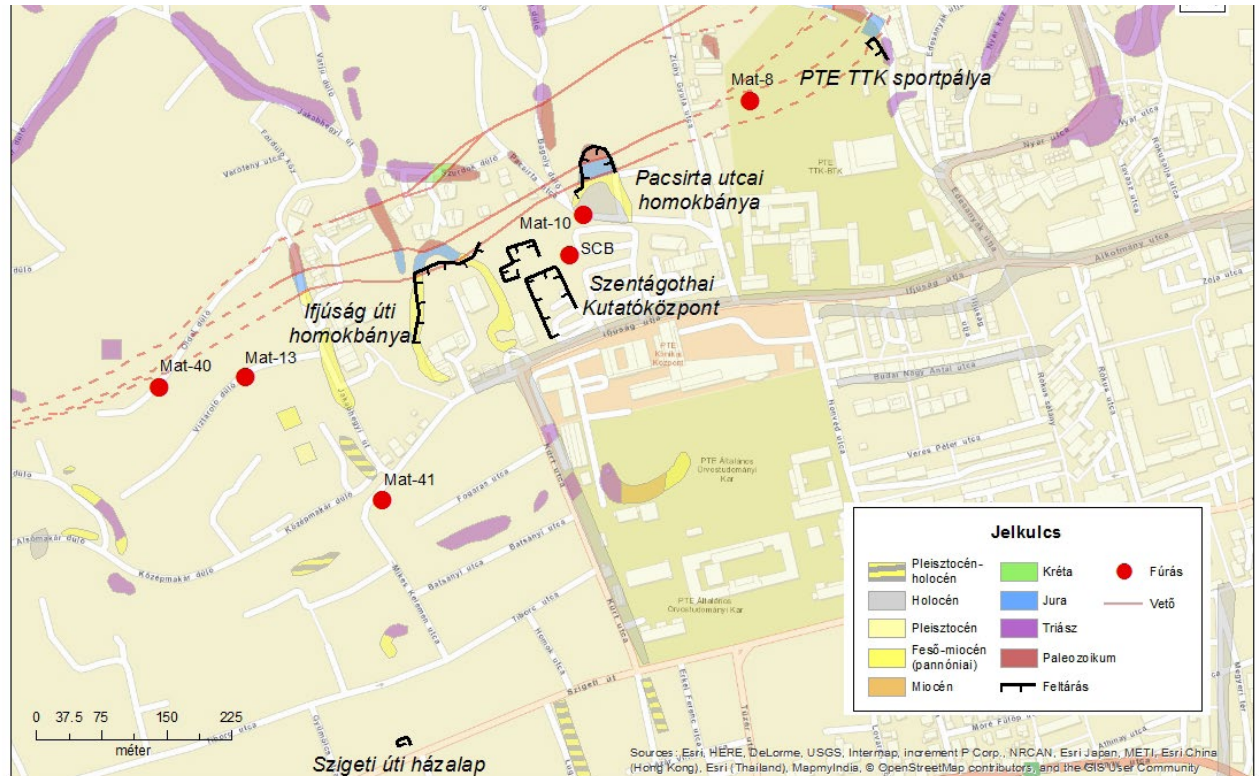

2. ábra: A vizsgált feltárások és fúrások elhelyezkedése és földtani környezete (földtani észlelési adatok Chikán \& Chikánné $(1978,1982)$ és Chikán, Chikánné \& Kókai (1979) alapján, módosítva)

kőfejtőként is említi. Cikkében ebben a bányában, valamint nyugati és keleti folytatásában (Jakabhegyi út, illetve Pacsirta utcai homokbánya) vastag trachidolerit teleptelért említ a szeizi rétegek (ma Patacsi Aleurolit) és a jura szenes összlet között, tektonikusan érintkezve. A trachidoleritet szürkészöldnek és erősen préseltnek írja le, és tévesnek tartja Böckh János és Vadász Elemér korábbi határozását, akik gránitnak tekintették ezt a kőzetet. Leírt megjelenése és helyzete alapján Wein trachidoleritje megegyezik a mások által gránitként, gneiszként vagy migmatitként leírt közettesttel.

\section{Szentágothai Kutatóközpont}

A több épületből álló központ alapjait 2011-ben ásták, az Ifjúság úti homokbányától alig néhány tíz méterre. Ezek a bevágások nagy kiterjedésü, összefüggő feltárásokat jelentettek, melyekben a pannóniai homok és kvarter fedöje, valamint előbbiben a kavicsbetelepülések térbeli helyzete jól megfigyelhető volt. A központ fütését és hütését geotermikus rendszerrel oldották meg, melynek föld alatti csőrendszerét az épületegyüttestől északra helyezték el. Az ezzel járó földmunkák további részeket tártak fel a pannon-tavi homokból, valamint ennek köszönhetően került felszínre a homokra tolódott jura szenes összlet és metamorfit gyenge feltártsággal, de egyértelmüen azonosíthatóan a homokbánya ÉK-i végén, a két telek határán.

\section{Pacsirta utcai homokbánya}

A régen felhagyott homokbánya a Pacsirta u. 22. sz. ház mögött, tőle északra helyezkedik el. Leírását Chikánné Jedlovszky \& Kókai (1980) adja, hivatkozott észlelési magyarázójukban és 1983-as cikkükben, valamint a térképeken (Chikán \& Chikánné, 1978; Chikán et al., 1979) MA81-es feltárásként szerepel. A pannóniai homokra rátolódva 4 méter vastag jura köszenes összletet írnak le, melyen szintén rátolt helyzetben metamorfit található, ezt az általuk idézett Somogyi gneiszként azonosította (Chikánné Jedlovszky \& Kókai, 1980, MA.81 sz. feltárás; Somogyi, 1976a, 4664. sz. feltárás). A bánya fala mára jórészt leomlott, benövényesedett. A homokból kis foltok látszanak, a lejtőn lecsúszva megtalálhatók a homokra tolódott metamorfit tömbjei.

\section{PTE TTK sportpá-}

\section{lya}

A Pécsi Tudományegyetem Ifjúság úti campusának sportpályájától ÉK-re 20-30 méterre egy bevágás keleti falában évekig látható volt a pannóniai homok és homokkő, bár a fal alsó felét törmelék fedte. Ez a feltárás korábbi észlelési térképeken nem szerepel. A hely a PTE botanikus kertjéhez tartozik, a kert rekonstrukciója során 2015-ben rézsűzték és növényekkel ültették be, így ma már nem tanulmányozható.

\section{Szigeti út, házalap}

A Pécs, Szigeti út 46. sz. telken álló házat 2011-ben lebontották és helyére újat emeltek. A csak néhány hétig látható házalap pannóniai homokos rétegsort és kvarter fedőt tárt fel.

\subsection{Fúrások}

A terület fúrásos feltárása Pécs építésföldtani térképezésének köszönhető, amit az 1970-es években végeztek. A fúrások elnevezése az érintett térképlap nevéhez igazodott, a vizsgált területen a Mat (Mecsekalja térképező) jelü fúrások mélyültek. Térképező fúrások lévén mélységük rendszerint legfeljebb néhány 10 métert ért el, de ebben a tektonikus zónában ez több helyen elég volt ahhoz, hogy a laza üledékek alatt megfúrják az alaphegységi képződményeket is. Alapos földtani leírásuk értékes forrást jelent a későbbi kutatások számára. Ezen fúrások közül a Mat-8, -10, -13, -40 és 41 esik a vizsgált területre (2. ábra). A közelmúltban a Szentágothai Kutatóközpont építésének előkészítése során, 2009-ben mélyült a PTE Science Building geotermikus szondafúrás (SCB). Bár teljes szelvénnyel fúrták, a furadékminták alapján megállapítható volt az elért alaphegység mélysége és kőzetanyaga. 


\section{Módszerek}

A területről elsősorban kéziratos anyagok állnak rendelkezésre, a vizsgálatokhoz szükséges méretarányú (legalább 1:10 000-es) földtani térkép nyomtatásban nem jelent meg. Az archív térképi adatokat, így az 1970-1980-as években készült építésföldtani észlelési térképeket (Chikán \& Chikánné, 1982, Chikán et al., 1979), valamint Szederkényi (1970) Mecsekalja-övről készített észlelési térképét ArcGIS programmal digitalizáltuk. Az első lépésben elkészült 1:10 000-es méretarányú térképlapokról digitalizált feltárásokat kiegészítettük az 1:5 000 méretarányú térképlapokéval (Chikán \& Chikánné, 1978), amennyiben azok új információt hordoztak. Az egyes kőzetek kor szerinti elkülönítése a már hivatkozott észlelési térképek és az azokhoz kapcsolódó dokumentáció (Chikánné Jedlovszky \& Kókai, 1980) alapján történt. Ha az nem felelt meg a jelenleg elfogadott besorolásnak, az utóbbit vettük figyelembe. Így a Jakabhegyi Homokkő Formáció nem perm, hanem triász korúként kerül feltüntetésre. A különböző leírásokban ellentmondásosan megjelenő, eltérő kőzetként vagy rétegtani egységként megjelenített feltárásokat terepen vizsgáltuk.

Az elmúlt években keletkezett ideiglenes, valamint a ma is hozzáférhető régebbi feltárásokról terepi jellemzést készítettünk: megadtuk vázlatos rétegsorukat, leírtuk az előforduló üledékszerkezeteket, valamint a földtani környezetet. Saját megfigyeléseinket összehasonlítottuk a már nem vizsgálható feltárások (mint pl. a mára már leomlott homokfalak) archív leírásaival, illetve a környéken mélyült fúrások dokumentációival. Ezek elsősorban kéziratos jelentésekben voltak hozzáférhetőek (Chikánné Jedlovszky \& Kókai, 1980, Somogyi, 1976a, b), részletességük azonban sajnos nem minden esetben volt elegendő a mostani leírásokkal való korrelációhoz. Ahol lehetséges volt, ott mértük a rétegdőlést és a tektonikai elemek (elsősorban vetők) helyzetét.

Kiemelt figyelmet fordítottunk kavicsanyag megfigyelésére. Terepen rögzítettük a kavicsok kőzetanyagát a makroszkópos megfigyelés adta lehetőségekig, illetve a szállításra utaló bélyegeket, mint a koptatottság vagy mállottság. A jellemző vagy kérdéses kőzetekből vékonycsiszolatokat készítettünk és ezeket mikroszkóp alatt vizsgáltuk. A kavicsanyag forráskőzeteinek azonosításához bejárásokat végeztünk a környéken, és a kavicsokban megfigyelt kőzetanyagok szálban álló előfordulásait kerestük.

A korábbi leírások, fúrásdokumentációk leírásai és a terepi megfigyelések alapján a rétegsorokat a Golden Software Strater 4 programjával ábrázoltuk. A tektonikai adatok sztereogramjainak elkészítéséhez Jacques Angelier "Tector" nevü programcsomagját használtuk.

\section{Eredmények}

Az építésföldtani térképek és a hozzájuk kapcsolódó dokumentációk feldolgozása lehetővé tette egy összehangolt földtani térkép létrehozását (2. ábra). Ez megfelelö hátteret biztosít nemcsak az újabb megfigyelések rögzítéséhez, de a mások által közölt korábbi eredmények együttes megjelenítéséhez és értelmezéséhez is.

A feltárások jelenlegi állapotát fényképekkel dokumentáltuk (3. ábra). A rétegsorok üledékes jellegei az egyes feltárásban hasonlóak, ezért azokról közös leírást adunk.
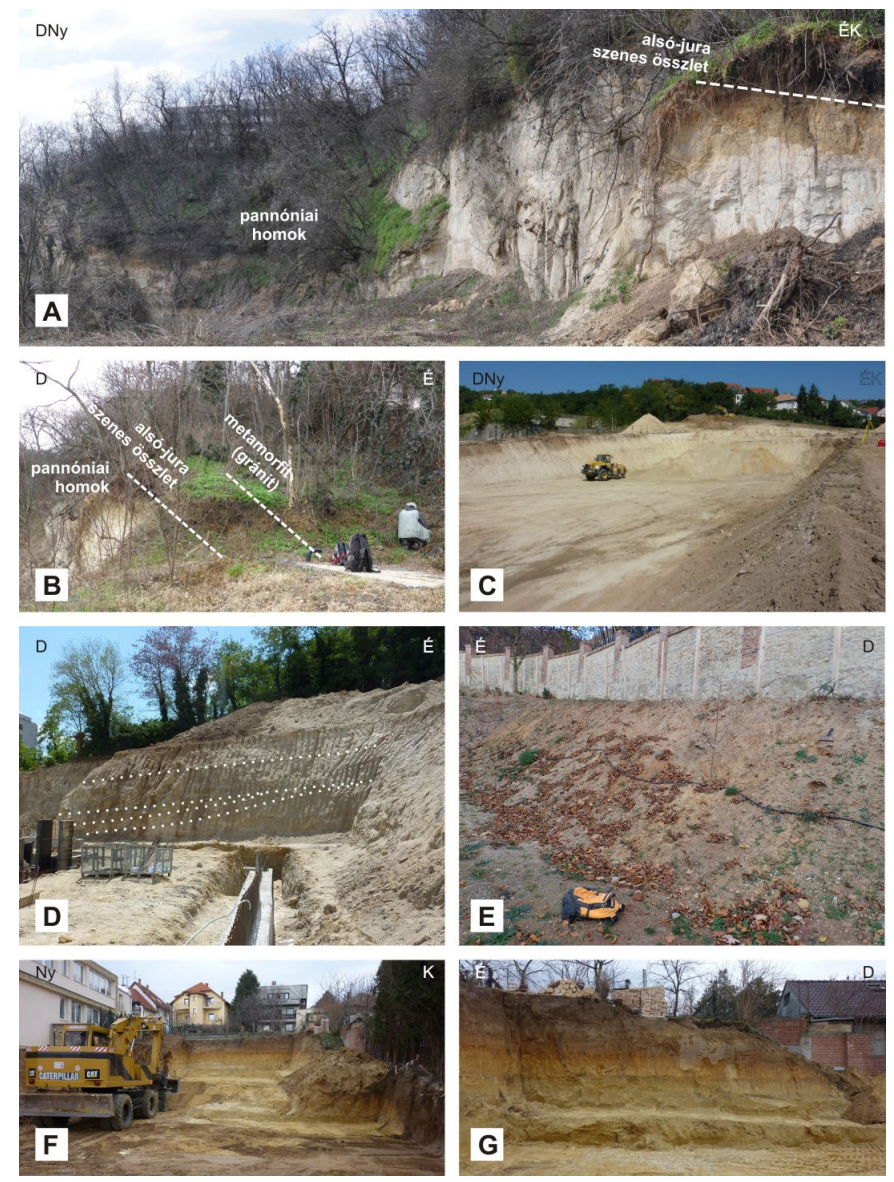

3. ábra: A vizsgált feltárások látképei

A) Ifjúság úti homokbánya a kutatóközpont telkéről fényképezve (2014 elején); B) Ifjúság úti homokbánya ÉK-i vége (2014); C) Szentágothai Kutatóközpont alapozásának alsó része (2011); D) az alapozás felsô része szétágazó kavicsrétegekkel (2011); E) PTE sportpálya melletti feltárás; jobbra fönt a kalapács alatt homokkőrétegek (2016); F) Szigeti úti házalap D-rôl (2011); G) a házalap keleti fala (2011).

\subsection{A pannóniai rétegsorok leírása}

A vizsgált pannóniai rétegsorok mindegyike kavicsbetelepüléses homokból áll. Átnézetes rétegsorukat a 4. ábra mutatja.

A feltárások mindegyikében a szürke vagy sárgásszürke, finom-középszemü, csillámos homok uralkodik. A durvább szemcseméretü betelepülések osztályozottsága 


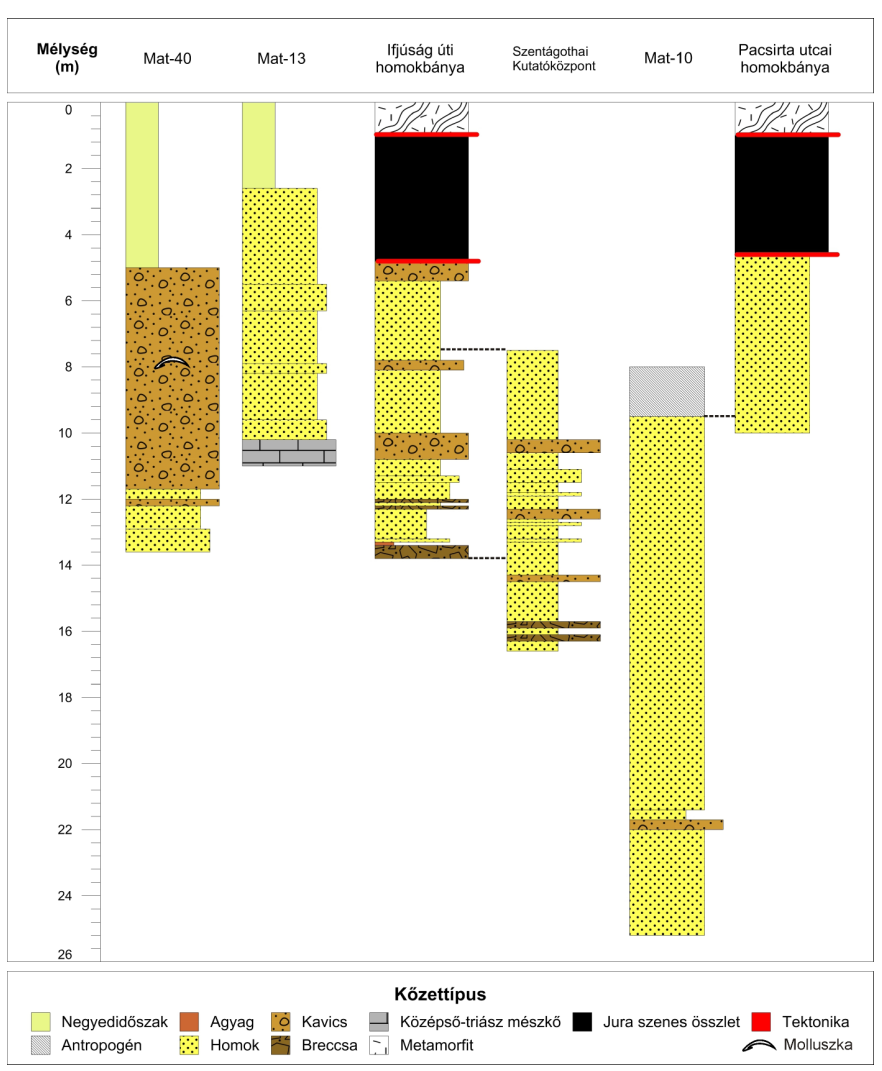

4. ábra: A vizsgált feltárások és a környékbeli fúrások rétegsora (saját adatok, valamint Chikánné Jedlovszky \& Kókai, 1980 alapján).

Az egymáshoz közeli, összeköthető fúrásokat és feltárásokat relatív magassági helyzetük szerint ábrázoltuk, kapcsolatukat szaggatott vonal jelöli.

jóval gyengébb, közép-durvaszemü homokból és/vagy kavicsból állnak. Vastagságuk néhány $\mathrm{cm}$-tôl néhány dm-ig terjed. Alsó határuk jellemzően éles, hullámos, eróziós, a fedőréteg felé többször fokozatos átmenetet mutatnak. A homokrétegekben jellemzően vályús keresztrétegzés figyelhető meg, a kötegvastagság elérheti a 30-40 cm-t (5. ábra F); ritkábban síklemezesek (5. ábra $G)$ vagy szerkezet nélküliek. A réteglemezek dőlésiránya változó, előfordul a hegység felé mutató is. A réteglemezek mentén gyakran osztályozódás figyelhető meg, a durvább szemcsék (pl. mállott földpátok) a réteglemezek talpa felé dúsulnak. A keresztrétegzés a durvahomok-aprókavics rétegekre is jellemző, míg a túlnyomórészt durva kavicsból álló betelepülések gyakran szerkezet nélküliek (5. ábra $B, E$ ). A homoknál finomabb szemü üledékeket az Ifjúság úti homokbánya és a Szentágothai Kutatóközpont alapozása alsó részén egy-egy vékony, max. $2 \mathrm{~cm}$-es agyagréteg képviselte. Az agyag mindkét feltárásban közvetlenül egy durva breccsaszint fölött települt (5. ábra E), jelenleg egyik helyen sem látható már.

Mind a homok, mind a kavics anyagú rétegek egyes helyeken mésszel cementáltak. A cementáció rétegszerü vagy foltszerü, cipós. Az északabbi feltárásokban (Ifjúság útja, Pacsirta u.) jellemzőbb, itt a homokban szinte mindenhol van valamennyi cement, kemény homokkö- vek is előfordulnak, míg délebbre a házalapokban ritkák a cementált rétegek. Mindegyik feltárásban megfigyelhetők limonitos színezésủ sávok vagy foltok; a limonit helyenként a rétegzést követi, néha attól teljesen függetlenül jelenik meg, elterjedését néhol vetők szabják meg (6. ábra D).

Azokban a feltárásokban, ahol dőlésirányú szelvény is látható, ott feltűnő, hogy a kavicsszintek délies irányba, a hegységtől távolodva széttartanak. A kutatóközpont alapjában például két kavicsréteg közt a távolság 10 m-es hosszon $30 \mathrm{~cm}$-ről $1 \mathrm{~m}$-re nőtt (3. ábra D). A kavicsrétegek legtöbbje csapásirányban sem kitartó: az egyes rétegek szétválnak, összefutnak, oldalirányban kiékelődnek, esetleg csak lencseként jelennek meg (5. ábra A). Az Ifjúság úti homokbányában egy durvakavics-zsinór csapásirányban 10 méteres távon több mint egy métert emelkedett, majd ismét vízszintessé vált. Összetételük gyorsan változhat oldalirányban, pl. egy vegyes anyagú kavicsszintben a kerekített kavicsok pár tíz méterrel arrébb teljesen elfogynak, a durva szemcséket csak éles kőzettörmelék képviseli (pl. az 5. A ábra kavicsrétegében).
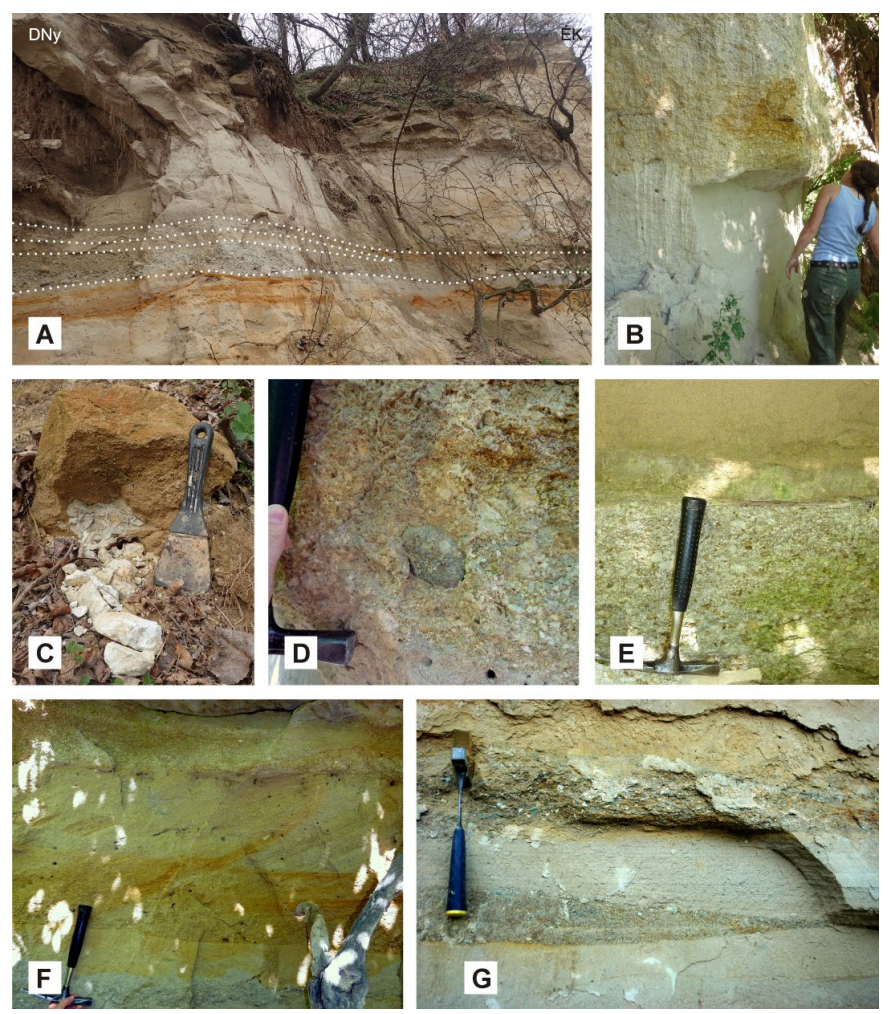

5. ábra: Részletek a pannóniai összletből

A) Szétágazó kavicsréteg jól koptatott és szögletes kavicsok keverékéból; B) vastag breccsaréteg metamorfittörmelékből; C) mállott metamorfittömb pannóniaihomokban "úszva" (leborult tömb); D) Kiválóan koptatott permi riolitkavics éles metamorfittörmelék között; E) breccsaréteg metamorfittörmelékból, vékony agyagzsinór (a kalapácsnyél végénél), majd homokkő és homok; F) keresztrétegzett homok; G) síklemezes homok két kavicsréteg között [Csillag Gábor felvétele]. A, C, E-G: Ifjúság úti homokbánya; B, D: Pacsirta utcai homokbánya. 
Emiatt az egyébként feltünő kavicsszintek nem használhatók vezetőszintként, már néhány tíz méteres távon sem korrelálhatók. Így az Ifjúság úti homokbánya és Szentágothai Kutatóközpont hasonló szintben lévő szakaszai nem párhuzamosíthatók, és a Pacsirta utcában mélyült Mat-10 fúrásban sincs kavicsréteg abban a magasságban, ahol az Ifjúság úti homokbánya sok kavicsréteget tartalmaz.

A Pacsirta utcai homokbányáról nem áll rendelkezésünkre részletes, a kavicsbetelepüléseket is bemutató rétegsorleírás, így a 4. ábrán csak jelképesen ábrázoltuk tiszta homokként. Somogyi (1976a, valamint in Chikánné Jedlovszky \& Kókai, 1980) finom-aprószemü homokot és ebbe települö 10-30 cm vastag, durvakavicsos homokbetelepüléseket ír le, összesen $10 \mathrm{~m}$ vastagságban. A 2011-ben a bánya alsó harmada környékén látható $3 \mathrm{~m}$ magas kis falszakasz változó szemcseméretü homokot és két, fehérre mállott metamorfittörmelékböl álló kavicsbetelepülést tárt fel (5. ábra $B, D)$. Ez alapján feltehetö, hogy a bánya rétegsora nagyon hasonló volt az Ifjúság úti homokbányáéhoz. A rétegsor folytatása lefelé viszont ismert: a Mat-10 fúrás (4. ábra) a bánya talpával egy szintről, az utca túloldaláról indult.

A PTE TTK sportpálya melletti, kb. 10 m hosszú bevágásban az elmúlt években nem látszott jól a felső-miocén homok, ezért pontos rétegsort nem tudunk adni róla. A rossz feltártság ellenére egyértelmüen megállapítható volt, hogy a rézsüt alkotó homokos üledék litofáciesei megegyeznek a környékbeli pannóniai feltárásokéval. A max. 2,5 m vastagságú rétegsort túlnyomórészt sárgásszürke és rozsdabarna, finom-középszemü, limonitos homok alkotja. A fal felső részén összesen $20 \mathrm{~cm}$ vastag, 2-3 rétegből álló, közép-durvaszemü, limonitos kötésű, kemény homokkő volt látható (3. ábra $E$ ), amely néhány fokkal DK felé dőlt (dőlése a rossz feltártság miatt nem volt pontosan mérhetö). A homokkő alatt alig cementált, homok mátrixú breccsa volt feltárva, amelynek kavicsanyaga koptatatlan, csillámos metamorf kőzettörmelékből állt. A feltárás a felső-miocén homok legalsó részét képviselheti, mert töle keletre kb. 20 m-re, a Fekete utca túloldalán, néhány méterrel alacsonyabban már anizuszi mészkőbe ásták a szülészeti klinika új, déli épületének alapját 2015-ben.

\subsection{Kavicsanyag}

A kavicsbetelepülések anyaga a vizsgált feltárásokban többféle. A következőkben felsorolt kavicstípusok gyakran magukban alkotnak egy-egy réteget, de keveredhetnek is.

1. Fehér, erősen mállott, koptatatlan metamorfittörmelék. Jellemző szemcsemérete a durvahomoktól a néhány $\mathrm{cm}$-es kavicsokig terjed. A legtöbb betelepülést ez az anyag alkotja (5. ábra $B, D, E)$, magában vagy más kavicstípusokkal keveredve (5. ábra $D)$. Több dm-es, koptatatlan tömbjei vastag homokrétegekben "úszva" is elöfordulnak (5. ábra C). Sürün, akár néhány mm-enként karbonáterek szövik át, emiatt írhatták le egy részét makroszkópos megfigyelés alapján karbonátként (Konrád \& Sebe, 2013).

A kavicsok látható szövete megegyezik a homokra feltolt kristályos kőzetekével. A pontos azonosítás végett vékonycsiszolatokat készítettünk a kavicsanyagból és a környéken szálban előforduló, a korábbi leírásokban metamorfit, gránit, migmatit, gneisz (Chikánné Jedlovszky \& Kókai, 1980, Somogyi, 1976a) és bazalt (Wein, 1966) néven szereplő kristályos kőzetekből. A makroszkópos megfigyelések és a csiszolatok alapján megállapítható, hogy a pannóniai homok és a jura szenes összlet fölé tolódott kristályos összlet változatos színei ellenére az Ifjúság úti és a Pacsirta utcai homokbányában, valamint a tőlük északra húzódó útbevágásokban (Szurdok dülö, Fekete utca) megegyezik. Ugyanez a metamorf kőzet alkotja a fehér breccsa-, illetve kavicsrétegek anyagát, erősen mállott formában.

2. Alig-közepesen koptatott, zöld és vörös agyagkő és aleurolit, világosvörös, barna és szürke homokkő (csillámos is), szürke dolomit és márga. Jellemzően 0,5-2 cm méretűek, ritkán nagyobbak, a $15 \mathrm{~cm}$-t is elérhetik. A vörös és zöld aleurolit és homokkő a középső-triász Patacsi Aleurolitból, a karbonátok a szintén középső-triász karbonátos sorozatból (Misinai Formációcsoport) származhatnak. Mindkét összlet előfordul a feltárásoktól északra 100-200 m-es távolságon belül. A szürke, finomszemü, csillámos homokkő kavicsok 4-5 cm-es méretet is elérnek. Anyaguk megegyezik a pannóniai üledékben szálban álló homokkőrétegek anyagával, azok újrafeldolgozásából származhat.

3. Jól vagy kiválóan koptatott kavicsok. Jellemző szemcseméretük $5-15 \mathrm{~cm}$, bár kisebb méretben is előfordulnak. Nagy részük kvarcit, riolit (a Gyürüfüi Riolitból; 5. ábra $D$ ) és gránit, de előfordul aleurolit, homokkő és sötétszürke, tömött középső-triász mészkő (Viganvári vagy Lapisi Mészkő) is, utóbbi néha molluszkahéj-átmetszeteket tartalmaz. Egyes típusok, mint a riolit vagy a gránit, nem fordulnak elő szálban a környéken, ahogy nagy kvarcitkavicsokat szolgáltató kőzet sem. Ez a felsorolt kőzettípusok jól koptatott kavicsaiból álló társulás jellemző ugyanakkor az alsó-miocén Szászvári Formációra. Ennek nem ismerjük sem felszíni, sem felszín alatti elöfordulását a környéken, bár kavicsanyaga gyakran megjelenik áthalmozva a Nyugat-Mecsek déli részének pannóniai üledékeiben.

\subsection{Tektonikai adatok}

A homokban a legtöbb vetőt az Ifjúság úti homokbánya falában észleltük (6-7. ábra), de előfordultak a Pacsirta utcai bányában és a kutatóközpont munkagödrének falában is. A Pacsirta utcában a feltárás kis mérete, a munkagödörben pedig a kőzetanyag laza volta miatt kevés az észlelés. 

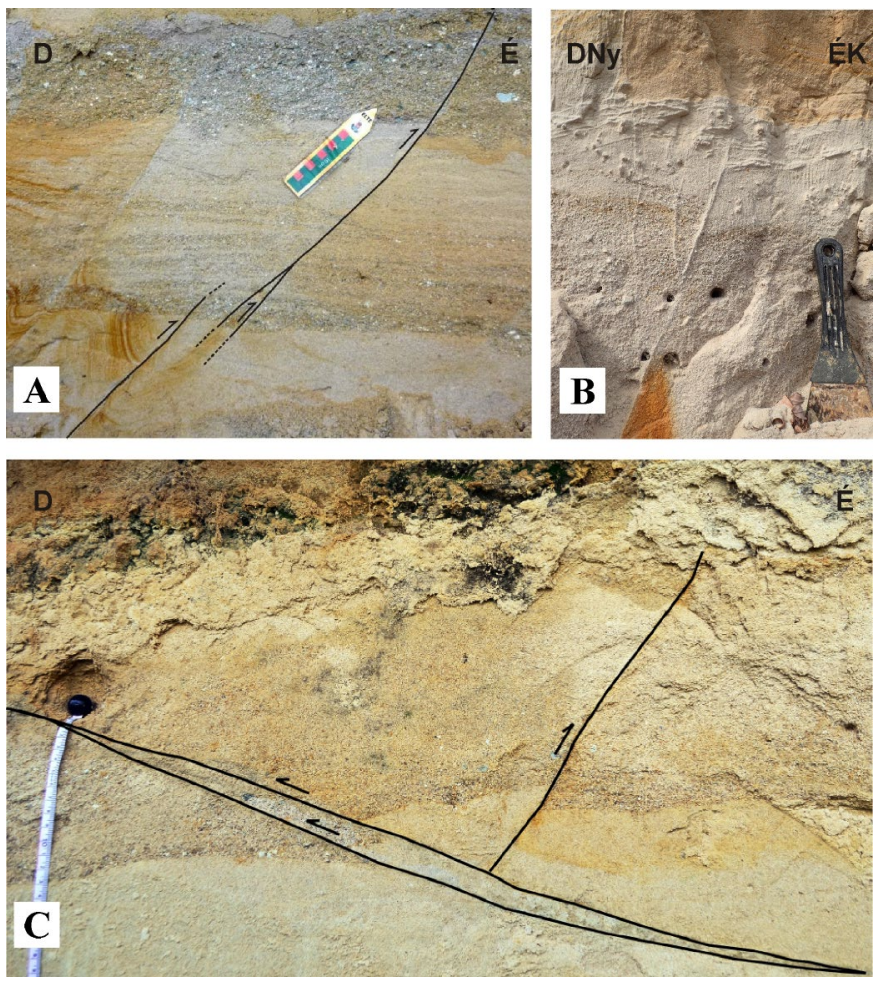

6. ábra: Az Ifjúság úti homokbányában megfigyelhető tektonikai elemek

A) Átlépő vető; B) Virágszerkezet; C) Antitetikus vetốk

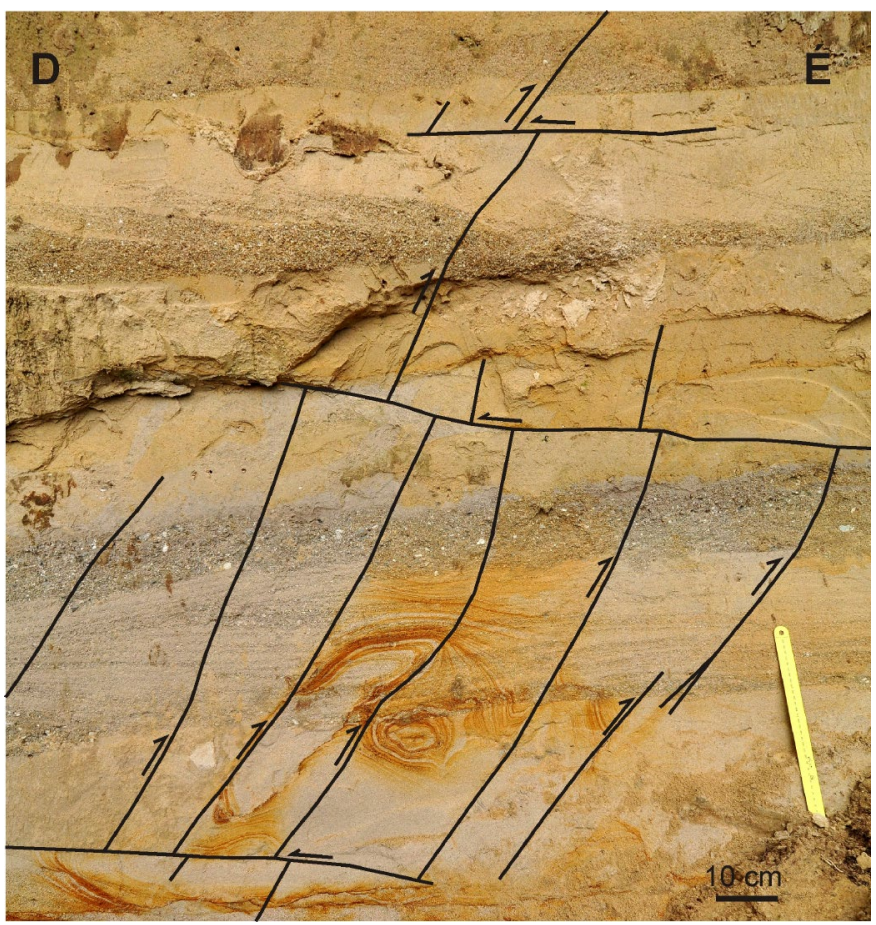

7. ábra: Szintetikus vetók, két egymást metsző vetógeneráció (Lantos Zoltán fényképe)

A vetők gyakran csoportosan fordulnak elő. Ezek ritkán követhetőek egy méternél hosszabban, lefelé, felfelé elvégződnek, ami szinszediment keletkezésükre utalhat. Az egyértelmüen egy generációhoz tartozó vetők között előfordulnak szintetikusak vagy antitetikusak (6. ábra $C$, 7. ábra), átlépő vetők (6. ábra $A$ ) és virágszerkezet (6. ábra $B$ ) is. Jellemző dőlésirányuk északi vagy déli ( 8 . ábra), ez a hajladozó geometria miatt kissé ingadozik. Vetőkarcok hiányában látszólagos elmozdulások állapíthatók meg az elvetett kavicsos durvahomok rétegek alapján. Az elmozdulás uralkodóan feltolódásos, az elvetés mértéke néhány $\mathrm{cm}$. Vetőkarcokat csak néhány oldalelmozduláson sikerült észlelni, ezek alapján azonban az elmozdulás iránya nem volt biztosan megállapítható.

A feltárásokban mért tektonikai adatok sztereogramjait a 8. ábra mutatja. Megfigyelhető, hogy a rétegdőlés délies-délkeleties, a hegységtől elfelé mutató, általában enyhe, de néhány esetben meredek, 30 fok fölötti. A vetők feltolódások, eltolódások vagy e két komponenssel rendelkező elmozdulások (az ábrán fekete vonallal jelölve). Normál összetevőjü vetőt egyetlen esetben figyeltünk
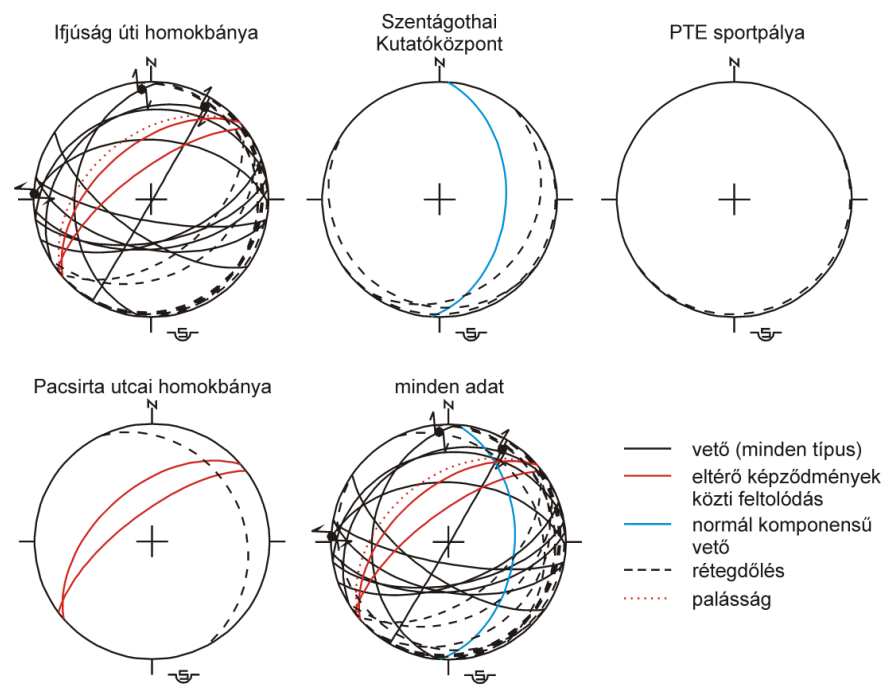

8. ábra: A feltárásokban mért tektonikai adatok (alsó félgömbi vetület)

A pannóniai homok és a rátolt alaphegységi blokkok közti feltolódások (pirossal jelölve), a palásság, néhány rétegdólés, valamint a Pacsirta utcai homokbánya adatai Somogyi (1976a) munkájából átvéve.

meg. A felső-miocén homok fölé tolódott metamorfit palásságának iránya megegyezik a képződmények közötti nagy feltolódási síkok orientációjával; e két adatot Somogyi (1976a) mérte.

\section{Az eredmények értelmezése}

\section{1 Üledékképződési környezet}

A viszonylag vastag, több dm-es kötegekből álló, vályús keresztrétegzésủ homokrétegek, valamint a síklemezes homokok erősen áramló vízre, itt litorális, azaz hullámbázis fölötti környezetre utalnak. A sok kavicsbetelepülés ellenére a rétegsorokban klasszikus abráziós kavics vagy konglomerátum - jól koptatott, helyi kőzetből álló kavicsréteg - nincs. A helyi, a környéken szálban megtalálható alaphegységi kőzetek törmeléke szögletes - ez azt 
jelzi, hogy nem történt hosszas, hullámzás általi mozgatás, ami lekoptathatta volna a törmeléket. Ez elöfordulhat úgy, hogy a törmelék azonnal a hullámbázis alá került (pl. a meredek part leomlása után, gravitációs tömegmozgással a meredek aljzaton), az ilyen mélyebb vízi környezetnek azonban ellentmondanak a homokban látható üledékszerkezetek. Az is lehetséges, hogy a törmelék az uralkodóan homokos felhalmozódási környezetbe kerülve rövid időn belül betemetődött.

A csak egyes rétegekben, eróziós rétegtalppal megjelenő kavicsszintek arra utalnak, hogy a durva törmelék epizodikusan szállítódott a tóba: az egyébként viszonylag finom szemcseméretű homokba időszakosan, egyegy eseményhez kapcsolódva érkezett durva homok és kavics. A törmelékbeszállítási események oka többféle lehetett. Kiválthatta intenzív csapadékos esemény. Ez a lehetőség azért nem tünik valószínűnek, mert a terület változatos kőzettani felépítése miatt már néhány 100 méter hosszú vízgyüjtőről történő lehordás is polimikt kavicsanyagot eredményezne, ami nem jellemző a feltárásokban. A relatív vízszint hirtelen megváltozása, a partvonal eltolódása is okozhat eróziót abrázió által; ezt szintén kiválthatja klimatikus esemény, de a hegység vertikális szerkezeti mozgása is. Törmeléket szolgáltathat továbbá vetőmozgás. Ha a vető felszínig hatol, és az $50^{\circ}$ körüli dőlésủ feltolódási síkok mentén a kristályos alaphegység egy-egy földrengés során némileg kiemelkedik, akkor az alátámasztás nélkül maradt, tektonikusan egyébként is erősen igénybevett, kis szilárdságú kőzettest leomolhat. Amennyiben ez a litorális zónában történik, az aprózódást segítheti a hullámverés is. Az omlás mellett szól a homokrétegekben magukban előforduló, több dm-es, koptatatlan metamorfittömbök jelenléte, melyeknek gravitációs úton kellett szállítódniuk. A tóba kerülő kisebb szemcseméretü kavicsot aztán a hullámzás keltette áramlások teríthették szét és szállíthatták el a parttól távolabb is: a metamorfittörmelékből álló kavicsrétegeket tartalmazó Szigeti úti házalap kb. 500 m-re van a forráskőzettől.

A kavicsok erős mállottsága nem az üledékképződés időszakában uralkodó felszíni mállási viszonyokat jelzi. A kavicsrétegek törmelékanyaga annyira mállott - sokszor kézzel morzsolhatók a kavicsok -, hogy ilyen állapotban nem tudott volna szétesés és koptatódás nélkül a tóba szállítódni. Ez alapján a mállottság már betemetődés után alakult ki.

\section{2 Ősföldrajzi kép}

A homokban található kavicsanyag alapján rekonstruálhatjuk az egykori lehordási területet. Amennyiben a fent írtak szerint a lehordás (omlások és abrázió által) nagyon kis távolságról történt, akkor egészen pontosan visszafejthető a terület felépítése.

A tanulmányozott feltárásokban a kavics- és breccsarétegek anyaga nagyrészt a homokra rátolt kőzettestekből vagy a közvetlen mellettük/fölöttük elhelyezkedő alaphegységi kőzetekből származik. Hasonló a helyzet több más, környékbeli fúrásban feltárt pannóniai rétegsor esetében is. A 300 m-rel nyugatabbra, a Makár-hegy déli lejtőjén mélyült Mat-40 fúrás valószínűleg triász mészkőből álló aljzat fölött mélyült, erre enged következtetni a vele csapásirányban elhelyezkedő, igen közeli Mat-13, valamint a kissé DK-re mélyült Mat-41 alaphegységi szakasza (2. és 4. ábra). Pannóniai konglomerátumaiban az uralkodó anyag a zöldesszürke agyagkő és agyagmárga (Chikánné Jedlovszky \& Kókai, 1980), ami a tőle közvetlenül északra kibukkanó Patacsi Aleurolit felső részének jellemző kőzete. A járulékos kavicsanyagok is azonosíthatók a területen egymás mellé tolódott képződmények anyagával: a „migmatit- és fillittörmelék” a homokra tolt metamorfittal, a „,vörös és zöld szemcsék” szintén a Patacsi Aleurolittal. A dokumentációban itt is említenek jól koptatott, permi homokkőként azonosított, akár 2-3 dm-es kavicsokat. Ezek a vizsgált feltárásoknál írtakhoz hasonlóan a Szászvári Formáció áthalmozott kavicsanyagát képviselhetik. A fúrásban a kavicsok koptatottsága változatos, az agyagkő a fúrás felső részén többnyire koptatott, lejjebb a zöldesszürke agyagmárga, a fillit és a migmatit jórészt koptatatlan (Chikánné Jedlovszky \& Kókai, 1980). A keletebbre mélyült Mat-13 fúrás változó mértékben koptatott kavicsanyaga a mészkőből álló alaphegység fölött kizárólag metamorf törmelék ("fillit, migmatit"). Itt tehát a Pannon-tó partját metamorfit alkothatta, míg a Mat-40 közelében már csak a metamorf sáv legvége lehetett az uralkodó Patacsi Aleurolit mellett. Közvetlenül a Mat-40 és a Mat-13 mellett (tölük északra) ma nincsen feltárása a metamorf kőzettestnek, a legközelebbi feltárás a Mat-40-től 200, a Mat-13-tól 100 m-re keletre fekszik. Feltételezhető, hogy a kavicsos homokhoz képest az alaphegység az üledékképződés után tolódott el, ez ebben az esetben jobbos oldalelmozdulást jelent.

Keletre haladva már bonyolultabb a kép. Míg a Pacsirta utcai homokbányában metamorfittörmelékből álló kavicsrétegeket láttunk, addig a bányától D-re 40-50 m-re mélyült Mat-10 fúrásban, ami a bányabeli rétegsor közvetlen feküjének tekinthető, a leírás szerint csak jól koptatott, bitumenes mészkő kavicsok fordultak elő a homokban. Középső-triász mészkövek, amelyek forrásul szolgálhattak, legközelebb innen ÉK-re ismertek a Mat-8 fúrásban; jelenleg a fúrástól közvetlen északra csak metamorf kőzetek, majd Patacsi Aleurolit fordulnak elő. A Mat-10 alatti alaphegység szintén mészkő: a Szentágothai Kutatóközpont építését előkészítő PTE Science Building geotermikus szondafúrás (SCB a 2. ábrán) furadékmintái a fúrómester elmondása szerint 26-30 métertől lefelé sötétszürke, tömött középső-triász mészkőből álltak. Ez a mészkő a két fúrás helyén a homok lerakódásával lefedődött, de a közelben felszínen, lepusztulási helyzetben kellett lennie. A metamorf kőzettest valamivel később kerülhetett ide, a rétegsor fölső részének a kavicsanyagát 
már ez szolgáltatta. A mészkő ezzel egy időben nagyjából elfedődhetett vagy eltávolodhatott, mert mészkőkavicsok csak az Ifjúság úti homokbányából ismertek, onnan is csak kis mennyiségben. A metamorf kőzettest keleti vége ma 400 m-re K-re van a Mat-10 fúrástól (2. ábra); ha a pannóniai üledéksor lerakódásának kezdetén még nem volt a fúrás mellett, akkor azóta legalább $400 \mathrm{~m}$ jobbos eltolódásnak kellett történnie, ha csak vízszintes elmozdulással számolunk. Mivel a vetőnek minden bizonnyal volt függőleges komponense is, a vízszintes elmozdulás ennél kisebb is lehetett. Jobbos eltolódást észleltünk az Ifjúság úti bánya homokjában is ( 8 . ábra).

Érdekes módon a sportpálya feltárásához igen közel, attól nyugatra mélyült Mat-8 fúrás nem harántolt pannóniai képződményeket, a 20 méter vastag negyedidőszaki üledék alatt meredeken álló középső-triász mészkőben állt meg. Ennek oka a pannóniai üledék utólagos lepusztulása lehet.

Szintén a mészkőtestek mozgására utal egy ma már alig látható feltárás a Mat-40 fúrástól 100 m-re DNy-ra, a Középmakár dűlő útbevágásában. Itt a pannóniai homokra középső-triász gumós mészkő tolódott, a homokban ugyanakkor nincs mészkőkavics, csak a most északabbra lévő Patacsi Aleurolitból származtatható zöldes színű agyagkő, aleurolit és homokkő (Somogyi J. leírása in Chikánné Jedlovszky \& Kókai 1980, 57. o., MA.135 sz. feltárás). Eszerint a mészkő itt is csak a feltárt homokösszlet lerakódása után került a homok szomszédságába. Hasonló, a homokra tolódott mészkőtestet említ Ferenczi $(1937,401$. o.) délebbröl, a mai Kürt utca nyugati oldaláról.

Olyan kavicsot nem találtunk, ami a jura szenes öszszletből származhat; ezek a kevéssé ellenálló litológia miatt valószínüleg nem örződtek meg, vagy a sorozat szürke homokkövei nem ismerhetők fel egyértelmüen a kavicsanyagban. Emiatt a szenes összlet késő-miocén helyzetét nem lehet nyomozni.

Nyitott kérdés az alsó-miocén Szászvári Formációból származtatható kavicsok eredete. A formáció ma nem fordul elő a környéken, általában a Nyugat-Mecsek déli oldalán máshol sem. A késő-miocénben ugyanakkor viszonylag nagy területen meg kellett még lennie, hiszen kavicsanyaga gyakori a pannóniai üledékekben. Erre utal az is, hogy pl. Patacstól nyugatra, Szentmiklós városrészben a szőlők között elszórtan ma is találni jól koptatott gránit- és riolitkavicsokat, olyan déli lejtőkön, ahová nem kerülhettek közvetlenül az ilyen kavicsokat szintén tartalmazó Jakabhegyi Homokkő főkonglomerátumából.

\subsection{Szerkezetfejlódés}

A forráskőzetek egykori helyzetének fenti rekonstruálása, valamint a megfigyelt tektonikai elemek alapján több fázisban történt szerkezeti mozgások nyomozhatók.

1. A területen a késő-miocén üledékképződés idejére már egymás mellett volt a ma feltárt, változatos anya- gú kőzettestek nagy része.

2. A homok lerakódása során további mozgások történtek, melyek mind az alaphegységi, mind a fedöhegységi kőzeteket érintették. Ezek alapvetően eltolódásos (talán jobbos) és feltolódásos összetevőjúek voltak, azaz transzpressziót jeleznek. Elegendő karcos vető hiányában feszültségtér-számítást nem lehetett végezni. A vetők orientációja és a forráskőzetek egykori helyzete alapján a legnagyobb horizontális föfeszültség iránya megközelítőleg ÉÉNy-DDK-i lehetett.

3. Hasonló kinematikájú mozgások a feltárt homokos rétegsor lerakódása után is folytatódtak.

A rendelkezésre álló adatok alapján az alaphegységi kőzetek a késő-miocén során és azóta legfeljebb $400 \mathrm{~m}$ horizontális elmozdulást és/vagy ennél kisebb kiemelkedést szenvedhettek a vizsgált területen. Az alaphegységi kőzetblokkokat illetően a homok lerakódásának idejére rekonstruálható földtani képből a mai állapot akár néhány 10 méteres függőleges mozgásokkal is előállítható. Ez természetesen nem jelenti azt, hogy valóban csak ekkora mozgás történt, csak annyit, hogy ennél nagyobbat nem tudunk bizonyítani ezen a területen. Ez az érték mindenesetre jelentősen kisebb, mint amennyit Hámor (1966) becsül, részben az általuk is vizsgált területre alapozva. Szerinte a Mecsek alaphegységi tömbjének miocén utáni kiemelkedése az előtérhez képest 500-600 m, egyrészt kelet-mecseki adat (a Zengővárkony-35 fúrás rétegsora), másrészt éppen a Makár-hegy szelvénye (az Ifjúság úti homokbánya) alapján. A teljességhez hozzátartozik annak kérdése is, hogy mit tekintünk a Mecsek elöterének. A hegység és környezete közti mozgások a Mecsekalja-öv mentén zajlottak, amely szélesebb, mint az általunk és Hámor (1966) által is vizsgált terület. Bár a Mecsekalja-öv legfontosabb vetői a vizsgált északi peremen helyezkednek el, és valószínüleg ezek mentén történtek a legnagyobb elmozdulások, a zóna délebbi részének kisebb feltolódásai is hozzájárulhattak a relatív emelkedéshez. Valószínütlennek tartjuk azonban, hogy ezek mozgása jelentősen (nagyságrendileg) módosította volna az összképet.

Konrád (1998) szerint a Pécs nyugati peremén mélyült 4582. sz. fúrás pannóniai kavicsanyaga alapján legalább 400 m-t emelkedett a fúrástól közvetlenül északra található alaphegységi sáv. Ha a mozgások az Ifjúság útjához hasonló módon történtek, akkor a 4582. sz. fúrás esetén is lehetséges, hogy a kavicsot a késő-miocénben még nem ez a kőzetsáv, hanem a mintegy $100 \mathrm{~m}$-rel északabbra elhelyezkedő mészkő szolgáltatta, és csak később került egy vékony "szelet" Patacsi Aleurolit a mészkő és a fúrással feltárt pannóniai kavicsos homok közé.

\subsection{Kor}

Ösmaradvány egyik vizsgált feltárásból sem ismert. A közelben az Ifjúság úti homokbánya és a Szigeti úti házalap között fekvő, rétegtanilag talán alacsonyabb 
szintet képviselő homokból (Kleb, 1973) került elő Congeria rhomboidea (régi Alsómakár úti [ma Tiborc u.] homokbánya, Vadász, 1960, 490. o.). Ez a kagylófaj a Congeria rhomboidea molluszka-biozóna jelzőfaja, a homok 8 millió évnél fiatalabb korát mutatja (Magyar \& Geary, 2012). A Mat-40 fúrásban $8 \mathrm{~m}$ mélyen, pannóniai konglomerátumban találtak Lymnocardium cf. proximum kagylót (Korpás Lászlóné határozása; Chikánné Jedlovszky \& Kókai, 1983). Ez a faj nem korjelző, de beleillik a Congeria rhomboidea biozóna molluszkatársulásaiba (Magyar I. ex verb.). A fent tárgyalt mozgások tehát a késő-miocén végén, a 8-6 Ma közötti időszakban, valamint ez után történtek.

\section{Következtetések}

A pécsi Ifjúság útja környékén megtalálható pannóniai homokos üledékek a késő-miocén viszonylag fiatal szakaszáról, a 8-6 millió év közötti időszak egy részéről tanúskodnak. A Pannon-tó hullámverése itt meredek, sziklás partot ostromolt, ahova betorkolló folyók nem szállítottak számottevő hordalékot. A homokba települő, koptatatlan törmeléket tartalmazó kavicsrétegeket legvalószínűbben szinszediment vetőmozgás üledékeiként értelmezhetjük; valószínűsíthető, hogy keletkezésük a feltolódások aktivitásához köthető.

A kavicsrétegek forráskőzeteinek azonosításával rekonstruálható az ősföldrajzi kép az adott időszakra, bizonyos pontossággal visszafejthető, hogy hol milyen anyagú kőzettestek helyezkedtek el. A változatos törmelékanyag arra utal, hogy az üledékképződés ideje alatt már egymás mellett helyezkedett el a Mecsekalja-övben ma látható, igen eltérő kőzettípusok nagy része. A forráskőzetek és a kavicsanyagok idő- és térbeli változásából megállapítható, hogy a vetőzóna egyes elemei a homokos rétegsor lerakódása előtt, alatt és után is mozogtak: az egymás mellé tolódott kőzetblokkok helyzete kis mértékben változott egymáshoz és a pannon-tavi üledékekhez képest is. Az elmozdulások túlnyomórészt eltolódásos és feltolódásos jellegüek voltak. A miocén óta a hegység emelkedése az elötérhez képest a Mecsekalja-öv mentén néhány 10 - néhány 100 m közé tehető.

\section{Köszönetnyilvánítás}

Köszönjük Magyar Imrének az ősmaradványok, Sztanó Orsolyának az üledékszerkezetek értelmezésében nyújtott segítséget. A munkát támogatta az OTKA (PD 104937), a Bolyai János Kutatási Ösztöndíj, valamint a TÁMOP 4.2.4.A/2-11-1-2012-0001 Nemzeti Kiválóság Program című kiemelt projekt, az Európai Unió támogatásával, az Európai Szociális Alap társfinanszírozásával.

\section{Irodalomjegyzék}

Chikán, G., \& Chikán, G-né (1978). Pécs város építésföldtani térképsorozata, Mecsekalja (3. sz.) 1:5 000-es méretarányú térképlap, Földtani észlelési térkép

Chikán, G., \& Chikán, G-né (1982). Pécs város építésföldtani térképsorozata. Magyarürög (5. sz.) 1:10 000-es méretarányú térképlap, Földtani észlelési térkép

Chikán G., Chikánné Jedlovszky, M., \& Kókai, A. (1979). Pécs város építésföldtani térképsorozata. Patacs (10. sz.) 1:10 000-es méretarányú térképlap, Földtani észlelési térkép

Chikánné Jedlovszky, M., \& Kókai, A. (1980). Pécs város építésföldtani térképsorozata. Patacs (10. sz.) 1:10 000es méretarányú térképlap. Földtani észlelési magyarázó I-III. Budapest.

Chikánné Jedlovszky, M., \& Kókai, A. (1983). Felső-pannóniai abráziós színlő a Misina-Tubes vonulat (Mecsek hegység) DNy-i oldalán. Magyar Állami Földtani Intézet Évi Jelentése az 1981. évröl, 249-261.

Ferenczi I. (1937). Adatok a Pécs környéki harmadkori medencerész földtani viszonyainak ismertetéséhez. $M a-$ gyar Királyi Földtani Intézet Évi Jelentése 1929-32-röl, 365-406.

Hámor, G. (1966). Újabb adatok a Mecsek hegység szerkezetföldtani felépítéséhez. A Magyar Állami Földtani Intézet Évi Jelentése az 1964. évről, 193-206.

Hámor, G. (1970). A Kelet-mecseki miocén. A Magyar Állami Földtani Intézet Évkönyve, 53(3), 1-371.

Kleb, B. (1973). A mecseki pannon földtana. A Magyar Állami Földtani Intézet Évkönyve, LIII(3), 750-943.

Konrád, Gy. (1998). A Ny-Mecsek késö-kainozóos fejlödéstörténete. Jelentés a Bodai Aleurolit formáció 19951998. évi kutatásáról. Mecsekérc Zrt. Adattár, Pécs, 58 p.

Konrád Gy., Sebe K. (2010). Fiatal tektonikai jelenségek új észlelései a Nyugati-Mecsekben és környezetében. Földtani Közlöny, 140(2), 445-468.

Konrád, Gy., \& Sebe, K. (2013). Perm-triász és pannóniai törmelékes üledékek a Mecsekben. Kirándulás vezetö, terepbejárás az MTA Szedimentológiai Albizottsága és az MFT Általános Földtani Szakosztálya szervezéséven, 2013.04.12-13.

Magyar, I., \& Geary, D. H. (2012). Biostratigraphy in a Late Neogene Caspian-type lacustrine basin: Lake Pannon, Hungary. In O. V. Baganz, Y. Bartov, K. Bohács, \& D. Nummedal (Eds.), Lacustrine sandstone reservoirs and hydrocarbon systems (Vol. AAPG Memoir 95, pp. 255-264).

Sebe, K., Konrád, Gy., \& Magyar, I. (2013). A legmaga- 
sabban fekvő mecseki pannon-tavi üledékek helyzete és kora. Földtani Közlöny, 143(1), 168-173.

Sebe, K., Magyar, I., Csillag, G., \& Sztanó, O. (2015). A mecseki pannóniai üledékek rétegtana: új adatok, eredmények és kérdések. In V. Dályay \& M. Sámson (Eds.), Tisia Konferencia, Pécs, 2015. február 27-28 (pp. 7276). Pécs: Magyarhoni Földtani Társulat.

Somogyi, J. (1976a). Pécs-Makár, Pécs bányatelep $\mathrm{M}=1: 10$ 000-es földtani térképre eső feltárások leírása [L-34-61-C-d-2 Pécs földtani térkép feltárásainak leírása. Mecsekérc Zrt. adattár, Pécs.

Somogyi, J. (1976b). Pécs és pécsbányatelepi egyesitett földtani térkép, 1:10 000. Magyar Bányázati és földtani Hivatal adattára, Pécs.

Szederkényi, T. (1970). A mecsekalja vonal földtani térképe Pécs városában. Pécs.

Vadász, E. (1935). A Mecsekhegység. Budapest: Magyar Kir. Földtani Intézet.

Vadász, E. (1960). Magyarország földtana. Budapest: Akadémiai Kiadó.

Wein, G. (1966). Pécs hegységszerkezeti képe: MTA Dunántúli Tudományos Intézet 
